\title{
Haunted Bodies: \\ Cell Switching, Getting Lost and Adaptive Geographies
}

\author{
Jane Grant \\ School of Art, Design and Architecture, \\ Plymouth University, UK \\ jane.grant@plymouth.ac.uk
}

\author{
Joanne "Bob" Whalley \\ School of Humanities and Performing Arts, \\ Plymouth University, UK \\ bob.whalley@plymouth.ac.uk
}

Received 2 June 2017; accepted 5 October 2017; published 21 November 2017.

\begin{abstract}
This article proposes the ideas of stochastic resonance and noise as devices with which to think of the body or self as plural and porous. Boundaries and surfaces are proposed as indefinite; cell switching and narratives of the self are discussed in relation to external forces, via Arendt's inter-subjectivity and La Celca's colonization as infection. The sonic artwork Ghost, which uses models of spiking neurons to materialize endogenous and exogenous composition in relation to noise and sonic memory is presented as an exploration of the boundary or limit of the notion of self. This paper, which serves as a cogitatum (a force) rather than cognitio (the result), articulates the human body as a complex and open system that steers towards chaos by adapting and accepting further complexity as, and within, constantly adaptive networks of creativity. We suggest that by focusing on the porosity of boundaries and the mechanisms that underlie their permeability, problems around identity and subjectivity might be seen in a new light.
\end{abstract}

Keywords: boundary; cell switching; hauntings; heteropathic exchange; sonic memory; surface; symbiogenesis; transfection.

This writing, produced through two disparate bodies in two distinct fields, serves as a cogitatum (a force) rather than cognitio (the result). This writing "between two" is an attempt to look at that which is captured, and that which escapes the frame. It is an action where "the event of performance can be said to enact the crisis of representing something fleeting and phantasmatic that persistently proliferates outside of its frame" (Alifuoco, 2017, p. 128). Its narrative begins from an articulation of the 
human body as a complex and open system that steers towards chaos by adapting and accepting further complexity, and pervades the constantly adaptive networks of creativity. As in the yoked researchers generating this paper, cogno-innovative knowledges serve as "an endless cycle of exploration, exploitation and explanation" (Gummerum \& Denham, 2014, p. 586) that can both cleave apart and together new understandings of the corporeal.

\section{Porous Boundaries of the Self, the Cell and the City}

At the level of single cells or their small clusters, our bodies are both endogenous and exogenous, responding both to internal and external sources, the skin the seeming boundary of our selves a porous envelope. In their paper "Nature, Nurture, or Chance: Stochastic gene expression and its consequences" Arjun Raj and Alexander van Oudenaarden (Raj \& Oudenaarden, 2008) present a study of cell switching in which small groups of cells commit a proportion of their population to stochastically "attune" themselves to exteriority. These groups of cells resonate with the external environment and become peripheral, whilst still embedded in the biological host. This seemingly random attribution of a portion of cells, allowing a simultaneously inward and outward focusing, resonates with the biological metaphor the artist and writer Victor Burgin offers in his essay “The City in Pieces” (Burgin, 1993/2009). The biological narrative he offers positions the city-scape as not only porous, but requiring the subject encountering the city to become soluble, allowing for the experiencing of a Freudian oceanic-bliss to emerge as she becomes "at-one" with her surroundings. For Burgin, this shift to a more porous city is a by-product of the softening of political boundaries, assailed by market forces, which require a freer movement of capital, which he articulates as "the economic and political equivalent of 'osmosis'the movement of fluid through a semi-permeable membrane, from the weaker to the stronger solution" (Burgin, 1993/2009, p. 236). Surely, this transformational osmosis also imbues "a pathological horror of mixing" (p. 236) with fluctuating systems of kyriarchical implications: responding to interconnecting social structures of domination, oppression, and submission.

The pathological horror to which Burgin refers reinforces further the biological narrative as a means to understand the social, developed by Franco La Cecla's narrative of infection (La Cecla, 2000) in which he counsels cautions in those moments of traversing unfamiliar territories, warning that when we travel, we are in danger of "colonizing with our presence every step of the journey" because "[t]o know new places corresponds in this century with denying their difference" (La Cecla, 2000, p. 34). We are borrowing here from the writings of theatre academic Nicolas Whybrow (2005), who positions Burgin and La Cecla in dialogue, but we offer our own development of his reading through the cellular understanding of the heteropathic and cannibalistic via the writing of Kaja Silverman (1992), who offers a further note of caution. For 
Silverman, when the subject aims to go outside the self, which might be akin to Burgin's solubility, rather than an oceanic feeling of oneness, the exchange is cannibalistic. As newness is experienced, the subject cannot help but absorb the novelty, and what results is a heteropathic exchange in which the self is protected at "the expense of the other who is in effect 'swallowed'" (Silverman, 1992, p. 205).

\title{
Symbiogenesis as a Form of Haunting
}

In an echo of Silverman's process, Donna Haraway (2003) offers a kind of phantasmatic exchange, when she imagines a ghosting of her cells by those of her dog's: that some sort of exchange is occurring at the macromolecular level. She refers to this cell-mediation as "transfection":

\begin{abstract}
Ms Cayenne Pepper continues to colonize all my cells-a sure case of what the biologist Lynn Margulis calls symbiogenesis. I bet if you were to check our DNA, you'd find some potent transfections between us. Her saliva must have the viral vectors. Surely, her darter-tongue kisses have been irresistible. ... I'm sure our genomes are more alike than they should be. Some molecular record of our touch in the codes of living will surely leave traces in the world, no matter that we are each reproductively silenced females, one by age and choice, one by surgery without consultation. Her red merle Australian shepherd's quick and lithe tongue has swabbed the tissues of my tonsils, with all their eager immune system receptors. Who knows where my chemical receptors carried her messages or what she took from my cellular system for distinguishing self from other and binding outside to inside? (Haraway, 2003, p. 15)
\end{abstract}

Both Haraway and Ms Cayenne Pepper's abject kisses, and the osmotic principle outlined by Burgin, cause a social horror, not because of what is absorbed, but because the resulting admixture is foreign; the host is haunted by that which it consumes. Quite what, or who, is being ghosted here in any given moment, we are not fully sure, but we feel that the inevitable (at least) doubling that occurs in these moments results in more than a simple consumption: a both-and pharmakon of cellular understanding.

These transfections unsettle the autopoietic state, which the writing of Niklas Luhmann (1999) extends beyond biological scapes, towards non-biological systems. Luhmann, a sociologist interested in systems theory, describes the relationship between environment and systems thus: "[t]he environment receives its unity through the system and only in relation to the system ... It is different for every system because every system excludes only itself from its environment" (Luhmann, 1999, p. 17). An autopoietic system reproduces itself from within itself, and is able to reproduce and maintain itself. For Luhmann, the human agent sits outside such systems, with a focus upon the strict adherence to boundaries central to his thinking. And this is where the autopoietic fails as a way for us to understand systems, as its hermetic nature seems to preclude the messiness that we experience as humanthings carried around by a constantly mutating meat sack. Human-things occupy the 
position of abject, where the abject refuses to "respect borders, positions, rules" rather disturbing "identity, system, order" (Kristeva, 1982, p. 4). The assumed guarded nature of the boundary defends against encroachment, keeps the surface intact and the "messiness" contained.

\section{Information Exchange as a Kind of Haunting; the Self Passing through the Boundaries of the Self}

Freud proposes that the skin, the seeming surface and boundary of the self, is crucial in understanding the construction of the psyche. This "energetic" boundary is at once both a physical and psychical entity with interchanging internal and external representations. The architect Jane Rendell $(2017$, p. 6) quotes the philosopher Elizabeth Grosz: “On the one hand, the ego is on the 'inner' surface of the psychical agencies; on the other hand, it is a projection or representation of the body's 'outer' surface".

In daily use, we tend to think of ourselves as being inviolable, with the barrier of the skin as sacrosanct, as something that it is broken through by accident or medical necessity. The scalpel or the graze blurring the boundaries of where the body ends and begins. This is an explicit moment of trauma.

And there is an explicit moment of trauma built into this writing. This writing began as a presentation, and acknowledges the ghosting between its authors, but also extends this to include the haunting presence of the reader. It references what FischerLichte (2004/2008) calls the "bodily co-presence" of performer and audience (p. 38). It thus entertains and holds within it embodied knowledges. Dubreuil (2015) further describes this haunting as an "intellective space":

We say more than we think; we think more than we say. This does not sum up all of our lives, but, at least, it describes where we are now, you and me, and where we stand each time we reflect on something or exchange ideas and signs. This strange place, I call it "the intellective space," that is, a putative space where thought and knowledge are performed and shared. (Dubreuil, 2015, p. 3)

This intellective space recognizes that knowing is inseparable from the doing, and that all knowledges are situated and performed in social, cultural and physical contexts.

\section{Sensory Systems as Mechanisms for Negotiating, Rejecting and Assimilating the Self and the Other}

This intellective space creates problems for the moment where the words on the page are loosened from the bodies that speak them. André Lepecki (2004) problematizes the theorization of performance ephemerality as "the body's self-erasure in time" (p. 5). He suggests we consider how that "presence" challenges the very stability of the body, how it can shift our cells. We can never witness ourselves at a cellular level, except through the mediated force of medical technologies. And as with any 
mediated forces (see the extended debate between Phelan and Auslander in the field of performance studies), the mediated is always something other than the thing itself. It is a thing that stands in for, and arguably, in Western medical parlance, where new technologies increasingly replace the "touch" of the physician, it is possible to think of this lacuna between the cell and the self as the apotheosis of Baudrillard's simulacra (Baudrillard, 1988).

Whilst moving about the world, we are continually aware of things, beings, and objects, of phenomena, on vast or minuscule scales, our bodies, senses, thoughts and memories, focusing on, or filtering out, information. Retelling Sigmund Freud, recent neuroscientific research states that it is our subconscious that shapes our experience of reality, that the internal and inaccessible parts of our being are the foundation for how we live in the world (Big Think, 2016). Our sensory systems are a dynamic mechanism for negotiating, rejecting and assimilating systems of other things at the level of movement, touch, taste and smell, and also at the level of cells, the body's unconscious, epigenetic realm.

\section{Noise as the Source of Intersubjectivity}

The paper "Nature, Nurture, or Chance: Stochastic Gene Expression and Its Consequences" by Arjun Raj and Alexander van Oudenaarden (2008) presents a study of noise, cell switching and fluctuation in single and small group studies of cells. The authors discuss a study in which small groups of cells commit a proportion of their population to stochastically anticipate the arrival of food sources. This is a neater way of detecting food and a viable and probable alternative to a situation in which cells firstly sense food directly in their environment and only then activate their metabolic network. The former strategy shows that "stochastic switching is a viable alternative to sensing and that it is most effective when the switching rate is closely tuned to the rate at which the environment fluctuates" (Raj \& van Oudenaarden, 2008 , p. 221), or resonates, even when this strategy sacrifices the switching group to "suboptimal" growth.

This noise in the bodies of things and beings, resonating with multiple exteriors of the other things and beings, points to the necessity of thinking of the self as a mutable fluid thing, the surfaces of the self negotiable. We are already inter-subjective.

How do we know that we are a self? Is it the narrative of time, of stories, of experiences, of memory? In his novel Invisible Cities, Italo Calvino (1972) writes that in looking into darkly reflective surfaces we may see ourselves, the lives that we may have lived, the characters we may have been, had our seemingly linear paths taken a different route. Hannah Arendt's inter-subjectivity places plurality at the center of selfhood, an inversion of subjectivity, where the inner life of the subject converses freely with the world, where subjectivity 'is turned 'inside out,' like a glove, and enacts itself in the world. It is out there in the world and it is of the world in the fundamental sense 
that being and appearing coincide" (Loidolt, 2014, para. 3). Here we regulate our personal relations between our internal world, our narrative and that of the external, of people and societies, developing a form of relationality in which we might form and reform concepts of the other, the alien, the imaginary and the abstract. Stories and narratives are where our imagination dwells, where we inhabit the inter-subjective place between worlds, between species, other timescales and the alien.

To point to or to name things, beings, or objects, it is easier to think of them as discrete, as bounded things or beings with definitive edges. To think of things, beings or objects as isolated between the individual and the world, the earth and the sky; the world and the solar system, for example, is to neglect the complexity of relationships between things and the effect that each thing has on the other; the gravitational tug of Saturn's rings, the gentle explosive effect of the production of hormones, the effect of the sun on our earth's ionosphere. Boundaries are relational, ever changing, mutable and often fluid. The resolving of our internal and the external narratives are a series of ever shifting boundaries. These porous and indefinite narratives or stories are a way in which we make sense of our world and the cosmos, of emotions, histories, futures and deaths.

\section{Nothing Is Ever Truly Discrete; Everything Bleeds into One Another}

One way to capture the ideas described in this paper is material form. The surface or "skin" of things or bodies are both exogenous and endogenous, an excitement of relations. Encountering our "outside material world" is a subjective experience; one that is both closed down and opened up by language. The complexity of our experience of things, of bodies, of relations and our movement is moderated by distinctions, at the edges of things. The architect Juhani Pallasmaa (2005) writes: "[t]he senses not only mediate information for the judgement of the intellect, they are also a means of igniting the imagination and of articulating sensory thought" (p. 45). Pallasmaa regards all of the senses as an extension of touch.

Karen Barad, the quantum physicist and feminist theorist, investigates the connection between the physical world and the world of relationships to quantum physics. Barad uses the term entanglements not only for matters of the quantum world but also to draw attention to relationships of enfolding or becoming with the "other." She describes how we are bound to the other and in developing Deleuze's différance writes that the relation of the self to the other is an entanglement, "a diffraction and dispersion of identity" (Barad, 2007, p. 9).

Here, the very nature of matter entails an exposure to the Other: "[r]esponsibility is not an obligation that the subject chooses but rather an incarnate relation that precedes the intentionality of consciousness. Responsibility is not a calculation to be performed. It is a relation always already integral to the world's ongoing intra-active becoming and not-becoming. It is an iterative (re)opening up to, an enabling of responsiveness. 
Not through the realization of some existing possibility, but through the iterative reworking of im/possibility, an on-going rupture" (Barad, 2010, p. 265). Barad also addresses the idea of intimacy and the impossibility of touch. At the center of touching something, or someone, is an electromagnetic interaction, it is an aversion of electrons within atoms, repulsion is at the core of attraction. It appears that forces, not things, are at the center of relations.

\section{Applying the Idea of Intersubjectivity as a Kind of a Haunting in a Material/Artistic Form}

In 2011, co-author Jane Grant made the artwork Ghost. At the core of the work was a small brain network that had been embedded with a sonic "memory," a drone sound that kept the network stimulated. The work was installed in the Maksem in Taksim Square as part of ISEA 2011 and the Istanbul Biennial. Once installed, live sounds picked up by microphones outside of the building in the busy Taksim Square stimulated artificial spiking neurons modeled in the computer to "fire," sending small fragments of sound to the eight speakers inside the building. If the external sounds fail to reach a particular threshold, the "memory embedded" sounds begin to be heard. Over time, the external sounds start to embed themselves into the model, gathering sensory information and sonifying both the past and the present, a form of cortical haunting. In space the microphones picked up the sounds of traffic, sirens and the Adhan from a nearby mosque. The sounds became fragmented, reconfigured, overlapping, a sonification of neurons firing with external and endogenous patterns and rhythms, sonic ghosts, merging the neural past with the neural present.

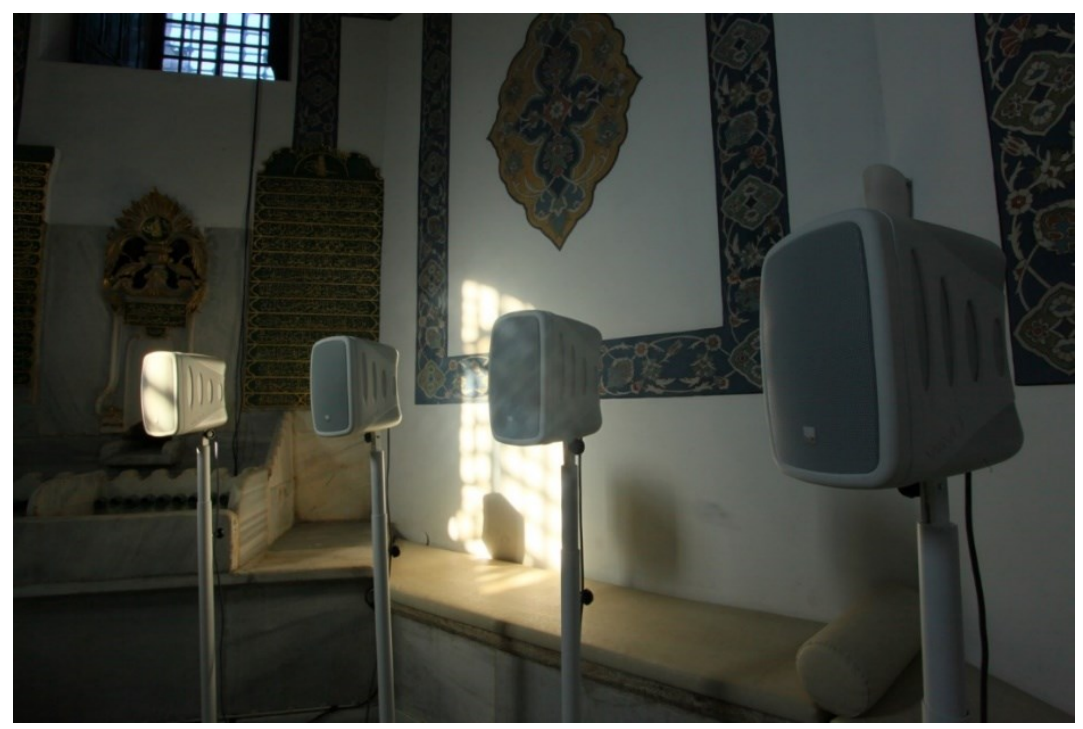

Figure 1. Grant, J. Ghost, ISEA Istanbul, Istanbul Biennial, 2011. 
If bodies are haunted, attuned to exteriority and mutability, and as Franco La Cecla (2000) writes, "we are molded by light, walls, mountains, and cities and learn how to mold ourselves in new landscapes and streets" (p. 30), how might we get lost within our own bodies, to rediscover their materiality? Grant's Ghost might then serve as an act of physical and theoretical palpation to explore the intellective space between the researcher-performers and audience, to acknowledge transdisciplinary narratives and begin to ask how we might open up the body as a site, one that can be understood as agentic, but not preeminent, within any given system of exchange.

\section{Acknowledgements}

We would like to thank our reviewers, Chris Germann and Diego S. Maranan, for their helpful comments on an earlier version of this paper.

\section{References}

Alifuoco, A. (2017). 'Alive' performance: Toward an immersive activist philosophy. Performance Philosophy, 3(1), 126-145. Retrieved from http://www.performancephilosophy.org/journal/article/view/87/179

Auslander, P. (2008). Liveness: Performance in a mediatised culture (2nd ed.). London, UK: Routledge.

Barad, K. (2007). Meeting the universe halfway: Quantum physics and the entanglement of matter and meaning. Durham, UK: Duke University Press.

Barad, K. (2010). Quantum entanglements and hauntological relations of inheritance: Dis/continuities, spacetime enfoldings, and justice-to-come . Derrida Today, 3(2), 240-268. doi:10.3366/E1754850010000813

Barad. K. (in press). On touching: The inhuman that therefore I am (v1.1). In S. Witzgall \& K. Stakemeier (Eds.), The politics of materiality. Chicago, IL: University of Chicago Press.

Baudrillard, J. (1988). Simulacra and simulation. In M. Poster (Ed.), Jean Baudrillard: Selected writings (pp. 166-184). Stanford, CA: Stanford University Press.

Big Think. (2016). Neuroscience confirms your subconscious shapes your reality. Retrieved June 2016 from http://bigthink.com/ideafeed/neuroscience-confirms-your-subconsciousshapes-your-reality

Burgin, V. (2009). The city in pieces. In A. Streitberger (Ed.), Situational aesthetics: Selected writings by Victor Burgin. Leuven, Belgium: Leuven University Press. (Original work published 1993)

Calvino, I. (1972). Invisible cities. San Diego, CA: Harcourt.

Dubreuil, L. (2015). The intellective space: Thinking beyond cognition. Minneapolis: University of Minnesota Press. 
Fiorenza, S. E. (1992). But she said: Feminist practices of biblical interpretation. Boston, MA: Beacon Press.

Fischer-Lichte, E. (2008). The transformative power of performance: A new aesthetics. (S. I. Jan, Trans.). London, UK: Routledge. (Original work published 2004)

Gummerum, M., \& Denham, S. L. (2014). Cognitive innovation: From cell to society. Europe's Journal of Psychology, 10(4), 586-588. doi:10.5964/ejop.v10i4.879

Haraway, D. (2003). The companion species manifesto: Dogs, people and significant otherness. Chicago, IL: Prickly Paradigm Press.

Kristeva, J. (1982). Powers of horror: An essay on abjection. (L. S. Rouidez, Trans.). New York, NY: Columbia University Press.

La Cecla, F. (2000). Getting lost and the localized mind. (S. Wylen, Trans.). Excerpts reprinted from A. Read (Ed.), Architectually speaking: Practices of art, architecture and the everyday. London, UK: Routledge. Retrieved June 2017 from http://www.darkmatterarchives.net/wp-content/uploads/2011/02/gettinglost.pdf

Lepecki, A. (2004). Of the presence of the body: Essay on dance and performance theory. Middletown, CT: Wesleyan University Press.

Loidolt, S. (2014). Hannah Arendt on plurality, spaces of meaning and integrity. Retrieved June 2017 from https://integrityproject.org/2014/09/30/hannah-arendt-on-plurality-spaces-of-meaning-and-integrity/

Luhmann, N. (1999). Social systems. (J. Bednarz, Trans.). Stanford, CA: Stanford University Press.

Pallasmaa, J. (2005). The eyes of the skin: Architecture and the senses ( $2^{\text {nd }}$ ed.), Chichester, UK: Wiley.

Phelan, P. (1993). Unmarked: The politics of performance. London, UK: Routledge.

Raj, A., \& van Oudenaarden, A. (2008). Nature, nurture, or chance: Stochastic gene expression and its consequences. Cell, 135(2), 216-226. doi:10.1016/j.cell.2008.09.050

Rendell, J. (2017). The architecture of psychoanalysis. Retrieved June 2016 from http://www.janerendell.co.uk/chapters/the-architecture-of-psychoanalysis-constructions-and-associations

Silverman, K. (1992). Male subjectivity at the margins. London, UK: Routledge.

Whybrow, N. (2005). Street scenes: Brecht, Benjamin and Berlin. Bristol, UK: Intellect Books. 


\section{Response to "Haunted Bodies: Cell Switching, Getting Lost and Adaptive Geog- raphies" by Diego S. Maranan}

Who am I, and what does it mean to be me given that I am also ever-changing? Confronting this dilemma, Denham and Punt (2017) suggest a process-the cognitive innovation function - in which being and becoming human are integrated into a unified explanatory framework. However, the underlying processes that contribute to the function are left for the reader to fill in. In Grant and Whalley's paper, one such process is suggested, organized around the role that boundaries play in mediating the (internal) self and the (exterior) other. A boundary defines that thing that it bounds. The skin, for instance, physically marks the extent of an individual; a city's borders not only circumscribe but define the city. However, the boundary is also a site of negotiation-for entries and exits, for information exchange, for movement. Negotiation at boundaries (this paper could be seen to suggest) is one of the processes underlying the cognitive innovation process. (Perhaps it is in this sense that the authors mobilize the concept of performance, though the discussion around this could be developed further, or parked for another discussion altogether.) Inspired by biology, the paper cites processes in living organisms that render boundaries temporary and porous: cell switching, osmosis, infection, and (to a lesser extent) autopoiesis. The authors then discuss examples in which biological processes might be seen to figure: cities, performance, relationships, art, architecture, cosmology. As an explanatory tool, metaphors are powerful but tricky: using processes occurring on the scale of cells as a metaphor for what might happen on the scale of human individuals or societies carries risk. For one, there is scale fallacy; the processes at play at one scale may not play a significant role in another (although properties and behaviors that operate on a smaller scale often create properties and behaviors that operate and are observable on a larger scale). Quantum effects are an example. However-and this is important to stress for the interdisciplinary audience of Off the Lip-this paper does not intend to propose an explanatory framework. Instead, what it offers is an invitation to reflect on what kinds of process happen in the boundary of living systems that might be able to account for the kinds of change that lead to the changes in the phenomena world, and to what extent these processes might be present, fractal-like, across scales.

A related concept to negotiation at boundaries is that of touch. The authors cite Palasmaa, with the idea that all of the senses are an extension of touch. It is worth noting that a precedent for this assertion is Rudolf von Laban (see Schiphorst, 2008, p. 195). Touch involves two boundaries coming into contact into each other and potentially transforming if not the boundary themselves, then that which the boundary bounds. In my research at CogNovo, and drawing on Shusterman's philosophy of somaesthetics, I highlighted the role that the act of touching a surface (and attending to the contact that one's body makes with the surface) contributes to knowledge not only 
about this exterior surface, but also to the state of one own's body. For example, I argued that a flat, horizontal, sufficiently springy surface allows one to make systematic comparisons of their proprioceptive and kinesthetic experiences while walking, standing, or lying down. Here, boundaries (the surfaces of the skin and of the environment) also instigate changes in the organism's perception of themselves. The literature on the theoretical dimensions of touch is substantial, but perhaps there is a gap in theorizing of the role that touch-in the sense of two surfaces in contact and in negotiation with each other-has in the evolution of cognitive systems across multiple scales.

\section{References}

Denham, S. L., \& Punt, M. (2017). Abstract of “Cognitive Innovation: A View from the Bridge." Leonardo, 50(2), 184-185. doi:10.1162/LEON_a_01386

Schiphorst, T. (2008). Bridging embodied methodologies from somatics and performance to human computer interaction (Doctoral dissertation). Plymouth University, Plyouth, UK. 